\title{
The balanced scorecard logic in the management control and reporting of small business company networks: A case study
}

\author{
Selena Aureli ${ }^{a}$, Andrea Cardoni ${ }^{b}$, Mara Del Baldoc and Rosa \\ Lombardid,1 $^{2}$
}

\begin{abstract}
aUniversity of Bologna, Italy; bUniversity of Perugia, Italy; cUniversity of Urbino Carlo Bo, Italy; dUniversity of Rome La Sapienza, Italy
\end{abstract}

\begin{abstract}
A bstract: The purpose of this paper is to assess and integrate the application of the bal ance scorecard (BSC) logic into business networks identifying functions and use that such performance measuring tool may undertake for SME's collaborative development Thus, the paper analyses a successful case study regarding an Italian network of small companies, evaluating how the multidimensional perspective of BSC can support strategic and operational network management as well as communication of financial and extra financial performance to stakeholders. The study consists of a qual itative method, proposing the application of BSC model for business networks from international literature Several meetings and interviews as well as triangul ation with primary and secondary documents have been conducted. The case study all ows to recognize how BSC network logic can play a fundamental role on defining network mission, supporting management control as well as measuring and reporting the intangible assets formation along the network development lifecycle. This is the first time application of a BSC integrated framework for business networks composed of SMEs. The case study demonstrates operational value of BSC for SME's collaborative development and success.
\end{abstract}

K eywords: management control, balanced scorecard, business networks.

J EL Codes: M00; M41; M49

${ }^{1}$ Corresponding author: Rosa Lombardi, University of Rome La Sapienza, Italy, email address sa.lombardi@uni romal.it 


\section{Introduction}

The strategic importance of collaborations between companies is now broadly recognised under an operative, scientific and institutional perspective. Technol ogical developments, social changes in consumer behaviour and deep interconnections deriving from globalisation arise growing complexities on the business environment (Håkansson et al., 2009), asking for more intense business collaboration (Mancini, 2016) able to enhance strategic and operational performance, especially for small and medium sized enterprises (SMEs). Therefore, policy makers, all over the world and at all territorial levels, firmly attempt to support the diffusion of strategic alliances (Huggins, 2001) to create synergies and to form international val ue chains consistent with the new industrial paradigms.

In line with this trend, in 2009, the Italian government promoted an innovative legislative framework ${ }^{i}$ represented by the contractual network - usually called network contract -, simplifying the formal arrangement to set-up and manage collaborative relationships (Cardoni, 2012; Lombardi, 2015). The intended aim of the Italian government was to promote more dynamic and flexible business aggregations, overcoming some weaknesses showed by the existing formal settings, such as consortiums, cooperatives and temporary business associations (Aureli \& Del Baldo, 2016a). Its goal was also to foster the formation of stable alliances to increase the competitiveness and innovative capabilities of the national productive system, mainly composed of SMEs (Cerved, 2015). As a specific contractual agreement bringing together firms to share information, co-produce, co-market and/or co-purchase, the network contract may support SMEs in reaching the critical dimension to bear innovative business development processes (Verschoore et al., 2015), accumulate experience, know-how, information and increase internationalization (Femhaber \& Li, 2013; Aureli \& Del Bal do, 2016a).

Italian contractual networks represent a promising field of study for management control in network settings as they have a distinctivecharacteristics: there is the legal obligation to explicit the strategic objectives that partners intend to achieve in the contract, the contents of the network programme and the criteria used to measure the progress towards the achievement of such objectives. This obligation calls for the definition of proper instruments for programming network's sactivities and managing and measuring performance within a network context (Mancini, 2016). New solutions are needed to support interconnection mechanisms between the partners' different business models.

At the same time, such requirements contrast the traditional reluctance of smaller enterprises to adopt management control systems as they are characterized by poor strategic planning and informal decision-making processes (Brouthers et al., 1998). SMEs weakly perceive the need for bal anced strategic control models (Hudson et al., 2001a) and adopt advanced control instruments only under specific conditions 
related to the governance structure and the management style (Hudson et al ., 2001a; Laitinen, 2002). In all other situations, SMEs adopt approaches easy to implement and consistent with SMEs' needs, notably, the need to focus on operational aspects that are critical for their success (Hudson et al., 2001b). SMEs prefer using informal and unstructured performance measurement practices because of their lack of human and financial resources, the prevailing reactive approach, their short-term strategic orientation, the difficulty in devel oping and formalizing mission and val ues, and the wrong perception of the benefits deriving from the implementation of a performance measurement system (Ates et al., 2013).

Starting from these premises, the aim of this study is to assess the application of a management control instrument based on the bal anced scorecard logic (hereinafter referred to as the BSC logic) within a reticular frame and, more specifically, in the field of contractual networks. In addition, this study aims to identify the functions that such an advanced instrument for performance measurement may undertake.

The empirical analysis focuses on the GPT network, a successful example of busi ness network created by 21 I talian SMEs. The case study proposed is directed to show results of the application of theBSC logic within contractual networks. Results support several research evidence and implications among which we highlight the capability of the BSC logic to reveal the alignment between the strategic decisions and the selection, measurement and control of financial and intangible performance, as well as the capability of this instrument to support network control, strategy implementation and the communication of results to stakeholders. In addition, the case of GPT network suggests that the BSC logic is devoted to monitor strategy implementation so far and not to challenge or revise the existing strategic di rection. The structure of the paper is the following. After theintroduction, section 2 presents the literature review and section 3 identifies the methodology. Sections 4 and 5 analyse the case study and findings. Section 6 discusses the results and ends with some cond uding remarks and our future research plan on the topic anal ysed.

\section{Application of the balanced scorecard in the field of small business company networks}

Although SMEs seem to not require sophisticated management control systems to implement and monitor strategies, due to their organizational simplicity and lack of formalization (Jänkälä, 2007), they could draw important benefits from the implementation of management control and performance measurement systems (MCS and PMS), especial ly in innovative settings and environment The integration between qual itative and quantitative metrics (Laitin, 2002) remains the best feature to al low the owner-managers to monitor a wide range of qual itative and quantitative goals (J arvis et al., 2000) even if recent literature demonstrates that the BSC logic does not assure per se a significant impact on decision-making performance (Strohhecker, 2016). In some cases, the use of strategy maps may have detrimental 
effects for organizations whose outcomes are influenced significantly by uncontrollable factors.

In the context of networks of SMEs the integration between qualitative and quantitative metrics is fundamental. They need different performance measures to capture network's objectives heterogeneity spanning from financial goals to the consolidation of the collaboration in terms of network's reputation, visibility, growth, members participation and rel ationships building. Financial indicators might not be abl eto capture the complexity of networks (Varamäki et al., 2008; Ferreira et al., 2012). Thus, the use of 'integrated' or 'balanced' metrics better support decision makers - the network manager in primis - to proactively and strategically manage the collaboration (Ferreira etal ., 2012). In addition, each small firmpartici pating the network may benefit from the collection and reporting of network performance measures to assess the results achieved by joint operations (Parung \& Bititci, 2008) or specific enabling factors (i.e, resources and competences, value and culture, and modes of interaction) (Varamäki et al., 2008).

To this extent, the BSC developed by Kaplan and Norton (1996) represents a dynamic and flexible tool that can be adapted to company networks to favor activity planning and network coordination (Hudson et al., 2001a; 2001b), increasing the SMEs awareness of the results achieved in relation to the network's objectives and reducing the risk of network's failure (Varamäki \& Vesalainen, 2003).

The BSC was originally intended as performance measurement tool (CIMA, 2005) characterised by the following elements (Kaplan \& Norton, 1996): the bal anced use of financial and non-financial measures to monitor results; attention to both short and long term objectives; simultaneous control of internal (eg., efficiency in processes) and external aspects (e.g., the satisfaction of customers or other stakeholders); the adoption of indicators that measure the drivers of success and therefore favour an indication on future company performance (leading indicator), together with indicators on past results (lagging indicator); stimulation towards continuous improvement; flexibility in its construction (perspectives and indicators should be created and modified according to company strategy) and its adaptability to every possible organizational context.

Cited characteristics make the BSC a managerial instrument effectively fitting in the field of company networks. The inclusion of non-financial measures regarding innovation, internal processes and customer satisfaction together with the flexibility and adaptability of the BSC (Atkinson, 2006) allow for implementation within a wide range of collaborative networks, as demonstrated by the following cases: consortiums created to develop new technologies and to carry out common R\&D activities (Kim\& Kim, 2009); public-privatepartnershi ps operating in the heal thcare sector whose objective is to satisfy the service users requirements (Cepiku et al., 2011); public service networks where citizen satisfaction represents the main 
perspective (Funk, 2007); tourism networks in which the private objective of creating shareholder value lives side by side with the public matrix objective of improving the image of the tourism destination (Aureli \& Del Baldo, 2016b). In all of these cases, traditional accounting measures and management instruments risk to become useless to the network manager whereas the BSC can provide a valid support.

Furthermore, in network contexts, the ability of the BSC to push management towards identifying and measuring all the possi ble success drivers that contribute to val ue creation (Eccles, 1991), including those of an intangible nature, becomes very important. In reticular contexts, socialisation mechanisms and knowl edge sharing between partners are more or less intentional ly activated and the BSC can contribute to understanding the importance of these intangible resources in the creation of a sustainable competitive advantage (Edvinsson \& Malone, 1997; Stewart, 1997; Sveby, 1997). Even though this is not a specific instrument of knowledge management, such as the Performance Prism (Neely et al., 2001) or the Value Creation Map (Marr, 2004; Marr et al., 2004), the BSC may still support management by identifying and monitoring knowledge, especially when strategic maps are used (Kaplan \& Norton, 2004).

An additional useful feature of the BSC in the field of collaborative networks consists of its attention to external forces, specifically referring to the key stakeholders who transfer tangible and intangible resources to see their specific expectations satisfied (Ahn, 2001; Funk, 2007). Even if the main sharehol der hol ds a predominant role in this framework (Neely et al., 2001), the BSC can be used to communicate with all partners, suppliers, customers and network funders and serve to monitor the level of satisfaction that is necessary to maintain and stabilize the network. In fact, the BSC is able to describe how the resources of the companies involved contribute to the network strategy (Laihonen et al., 2014), favouring partners' dialogue and socialisation along the value chain (Mahama, 2006) and balancing of the interests of various partners (Funk, 2007).

Summarising, theoretical literature suggests that the BSC is more than a simple management control tool. It is a framework that may have the following valuable functions (Busco \& Quattrone, 2015), when used in reticular contexts (Pekkola, 2013):

- clarify and describe the vision and mission of the network as key elements to define the strategies and expected results (Neely et al., 2000);

- implement the common network strategy, highlighting the causal links between strategy, activity and impacts on performance (Kaplan \& Norton, 1996; Atkinson, 2006), translating the objectives into specific action to be implemented (Epstein \& Manzoni, 1997) and acting as an operational standard to influence partners behaviour (Kulmala \& Lönnqvist, 2006; Mooraj et al., 1999; Lawrie \& Cobbold, 2004); 
- measure the network performance and monitor the achievement of the strategic goals (CIMA, 2005);

- improvemanagers' decision-making processes and contribute to theidentification of new emerging strategies (Simons, 1995; Kaplan \& Norton, 2001; Naro \& Travaillé, 2011);

- communicate network performance to stakehol ders and other thi rd parties (e.g. public authorities), in line with the tendency of using performance measurement instruments as an accountability tool (Marchi, 2011).

Such functions can be analysed in light of the Simons' framework (1995) as implemented by Van Veen-Dirks and Wijn (2002) with specific reference to the Balanced Scorecard.

Simons' framework provided that organizations should set four different types (or levers) of controls: beliefs systems, boundary systems, feedback systems and measurement systems, which can be used in a diagnostic or interactive manner. This distinction relates to how the information is used rather than the technical design features of the control system Diagnostic control systems (DCS) are used to set standards, monitor organizational outcomes and correct deviations. On the contrary, control systems are used interactively (ICS) when information outputs serve for communication within the organization and detecting strategic uncertainties that need to be addressed via informal dial ogueand other forms of interactions. Thus, the first type of controls supports the implementation of the strategy while the second type favours flexibility and strategic renewal thanks to informal communications that demand attention from managers and confrontation with the lower management levels. The main differences between ICS and DCS are reported in Table 1.

Table 1. Simons' framework applied to the Balanced Scorecard

\begin{tabular}{ll}
\hline \multicolumn{1}{c}{ Diagnostic C ontrol Systems (DC S) } & \multicolumn{1}{c}{ Interactive control Systems (IC S) } \\
\hline - Facilitate the measurement of the outputs & - Define a sub-set of important information \\
of a process & $\begin{array}{l}\text { to focus on given the strategic uncertainties } \\
\text { faced by an organisation }\end{array}$ \\
- Provide standards against which actual & - Favour frequent and regular attention \\
results can be compared & from operating managers at all levels on \\
- Correct deviations fromstandards & these information \\
& - Gather superiors, subordinates and peers \\
together to interpret and discuss the & information in the light of future strategic \\
initiatives
\end{tabular}

(Source: adapted from Van Veen-Dirks and Wijn, 2002)

In the attempt to apply Simons' framework to the usage of Balanced Scorecard within firms, Van Veen-Dirks and Wijn (2002) noted that this specific measurement system can be used interactively or diagnostically but cannot be adopted to perform 
the functions of a strategic control system, i.e. to review and reformul ate thestrategy. According to these authors, the BSC is a formal system designed for strategy implementation, thus when its data are used interactively, they can merely suggest strategy adjustments. The BSC does not really question the basis of strategic planning as strategic control systems do.

Simons' levers of control framework has been applied in many research over the last 20 years to interpret findings on empirical usage of management control systems and performance metrics (Martyn et al., 2016). Although developed from the author's study of intra-organizational controls within large enterprises, it provided helpful insights in the investigation of inter-organisational controls within networks (Kominis \& Dudau, 2012) and with reference to SMEs (Granlund \& Tai pal eenmaki, 2005). Past research has demonstrated that control systems can both measure resul ts to align network participants' performance and support partners to solve problems and search for opportunities when used to create a communicative environment within alliances (Mahama, 2006; Massaro et al., 2014).

Among the various performance measurement models for managing networks proposed in literature (Bititci et al., 2005; Ferreira et al., 2012), the Business Network Scorecard (BNS) is deemed rather interesting because of three distinctive elements (Lombardi et al., 2015). Firstly, it focuses on common network objectives (and not that of the leader or focal company), implying the adoption of a general shared vision of the network. Secondly, it adopts the network manager perspective, not considering the single company needs and tools to monitor the rel ations created with its suppliers (Kaplan et al., 2010). In other terms, it is designed to be a management tool for the network and not a tool of network relations management Lastly, it includes a fifth dimension of analysis, in addition to the four traditional dimensions (or perspectives) of the BSC, regarding the creation of value deriving from the reticul ar bonds created between the partners and the network towards the external environment These bonds may not be quantified in monetary terms, but they may lead to the development of new ideas or be translated in the creation of social valuefor thelocal context that can be measured in quantitativeand qual itative terms.

Therefore, this model adapts perfectly to the case of networks made by partners with equal decision power, where a focal company that guides collaboration does not actually exist, but there is a network manager who needs a governance instrument to simplify interactions and the exchange of information between partners and thanks to which he/she can monitor and report the results achieved, including those of an intangible nature.

Despite the growing interest on performance measurement system for networks and the diffusi on of contractual networks in I tal y (seeSection 1) that need to be managed effectively and efficiently, to dateno empirical application of BNS are available. To 
fill this gap we decided to investigate the possible application of the BNS model to the results achieved from a network of companies located in Central Italy used as a case study.

Based on the theoretical background described above, the research questions that have guided the empirical study are the following: 1) Can management control activities and reporting practices of a successful contractual network be interpreted to the multidimensional logic of the Business Network Scorecard model?; 2) Which functions and use can be recognised in the possible application of the BSC logic in the field of the contractual network investigated?

\section{Methodological approach}

To answer to above mentioned research questions, we adopted a qual itative research approach, basing the empi rical study on the anal ysis of the GPT (Gruppo Poligrafico Tiberino) contractual network. Similar to previous studies (Camarinha-Matos et al., 2009; Pekkola, 2013) one collaborative network forms the case study under investigation.

The case study method (single or multiple) has been widely used in the study of SMEs networks (Halinen \& Törnroos 2005; Barnes et al., 2012) and contractual networks (Aureli \& Forlani, 2016; Del Baldo, 2016; Trequattrini et al., 2012), al so facing the problems of performance measuring and accounting in the reticular contexts (Cardoni, 2012; Aureli \& Del Bal do, 2016b).

The analysis aims to check the possi ble application that the BSC logic ("the if") and the method of use ("the how") may have. The model can alternatively be used as a programming and control instrument, declined on a strategic and operativelevel (for the design of strategies and to identify the activities necessary to achieve the predefined objectives) and as a reporting and communication instrument of intangible strategic assets, aimed at reporting network performance with a multidimensional scope toward external stakeholders (Lombardi et al., 2015).

Consistently with the research objectives the inductive approach, widely used in international managerial literature (Flick, 2009) and typical of the Italian academic tradition (Ferraris Franceschi, 1990), allows for a better understanding of real situations through an in-depth analysis of complex phenomenon characterised by a high level of non homogeneity, novelty and/or dynamismsuch as networks of SMEs. Coherently, the case study method is suitable for experimental research strategies (Eisenhardt, 1989; Y in, 1989) to investigate into a contemporary phenomenon such as the contractual network, through the use of several sources of information such as interviews, questionnaires, archive data, documental analysis, analysis of information contai ned in websites, di rect and partici pating observationii . 
Froma methodological point of view, we decided to focus on this new form of interfirm collaboration because also relevant for EU policies (European Commission, 2008), which aim at creating the conditions for the sustainable growth and competitiveness of SMEs, representing more than 98\% of businesses in the EU-27 countries, empl oying $67 \%$ of the workforceand clearly contributing to territorial and communities innovation (Dobbs \& Hamilton, 2007; Fichter, 2009). The review of the 'Small Business Act' (European Commission, 2011) actually mentioned Italy and the network contract as a good practice to imitate, which is an absolute innovation and definitely of great interest and stimul us for European legisl ators si nce it fills a legal vacuum at the European level (see the chapter "Innovation and competence" of the 2011 'Small Business Act' review). Moreover, there is a widespread diffusion of this collaborative tool among Italian SMEs. Starting from the first network contract signed on March, $31^{\text {st }} 2010$ in Tuscany, latest national data (Unioncamere, 2016) indicate that the number of network contracts amounts to 3,243 and involve a total of 16,587 companies (respectively $+28 \%$ and $+30 \%$ over the last year).

With reference to the GPT case, this has been selected on the basis of three main attributes: 1) the medium-large dimension of the network (according to UnionCamere, the average number of companies partnering a network is 5, while GPT counts 21 partners or "nodes") and its organisational complexity, presuming the adoption of formalised management systems (Ahn, 2001; Funk, 2007); 2) the stability of the collaboration (launched since 2005) that justifies the costs associated to the creation of a management control infrastructure (Ferreira et al., 2012); 3) the dynamismand potential development of the network. Finally, the availability of the network's leader in collaborating has been taken into consideration, in particular the network manager, al ready involved in previous investigations (Saetta et al., 2013).

The GPT network has several elements of interest and excellence related to: a) the strategic collaboration model that overcomes the typical logic of vertical coordination of the partnership along the supply chain (Saetta et al., 2013); b) the organisational model of GTP as a collaborative networked organisation (Saetta et al., 2013), also configured as a "hybrid" network (Zapata \& Hall, 2012) whose "nodes" belong to the private and public sector; and 3) the development model, characterised by the increasing trend in economic-financial, social and environmental performance of the single partners and of the entire network. The dynamism, articulation and complexity of the network therefore make GPT a rather important context to understand if the currently adopted management control activities and performance measurement systems can be attributed to the multidimensional logic of the BNS model (Lombardi et al., 2015).

Themethodological process consists in verifying the possi bleapplication of the BNS model in threemain steps. Thefirst one includes the anal ysis of current management control systems and performance measurement systems adopted by GPT to show the 
performances that are kept under control. The second step involves the clarification of shared objectives that underlay these measures and their formalization into a matrix of objectives. The last phase refers to the design of a network-level performance measurement system, which takes the form of a multidimensional report, based on stated objectives and measures currently in use.

The use of the case study method as a strategy of investigation into a complex research area such us business networks requires paying attention to potential limits and some necessary precautions. As highlighted by Halinen and Tömroos (1998, 2005), four main problems has preliminarily to be analysed: the delimitation of the object of observation (the problem of network boundaries), network's complexity, the time factor and the comparison of cases.

Thefirst critical aspect has been faced by favouring the abductive approach (Easton, 1995; Dubois \& Gadde, 2002); we then identified the business context as a number of actors and relations between companies of the GPT, the network horizon (the horizon of perception, the macro-position and the relationscape) in terms of joint operations (the entire network) and excluded actions at the individual level (single company) in this phase. The approach adopted is based on the perspective of the network manager, formal ly appointed as Presi dent of GPT's Board of Directors. This role represents the meta-manager in charge of the (organisational, strategic and operative) coordination of each single node and of the system Therefore, he represents the key informant (Halinen \& Törnroos, 2005: 1291) from which information can be extracted, as a depositary of an integrated vision, past, present and future perspective of the network.

The second critical aspect, connected with the multidimensional nature of the network and its performance, has been faced through the use of a mix (triangulation) of information sources, by combining the primary sources of data (questionnai reand interviews) with the secondary sources (documental analysis, consultation of the official website, analysis of previous publications related to the GPT case), ai med at acquiring cognitive elements in order to answer the research questions as illustrated in the following figure (Fig. 1).

Specifically, three interviews were carried out with the President of the network during planned company visits (each lasting 2 hours, subsequently transcribed, coded and validated), in which the following aspects were discussed: the current structure of the network; the resources and financial structure of the network; the network objectives; the presence (and the type) of performance measurement instruments; the presence (and thetype) of key performanceindicators used to assess the achievement of network's objectives.

The President of GPT was also given a semi-structured questionnaire (Alonso, 2010), divided up into two main sections (for a total of 30 questions); the first aimed 
The balanced scorecard logic in the management control and reporting of small business company networks: A case study

at investigating into which accounting and managerial control systems are used on a network level and which reporting model has been adopted; the second (divided up into 5 groups of questions) aimed at checking if the logic incorporated in the theoretical model of the BNS can be found in the control systems currently in use.

The documental analysis was applied to both public documents (network's annual reports and the contract signed) as well as private documents for internal use elaborated by the network manager (management reports or progress reports).

Figure 1. The research strategy and sources of information

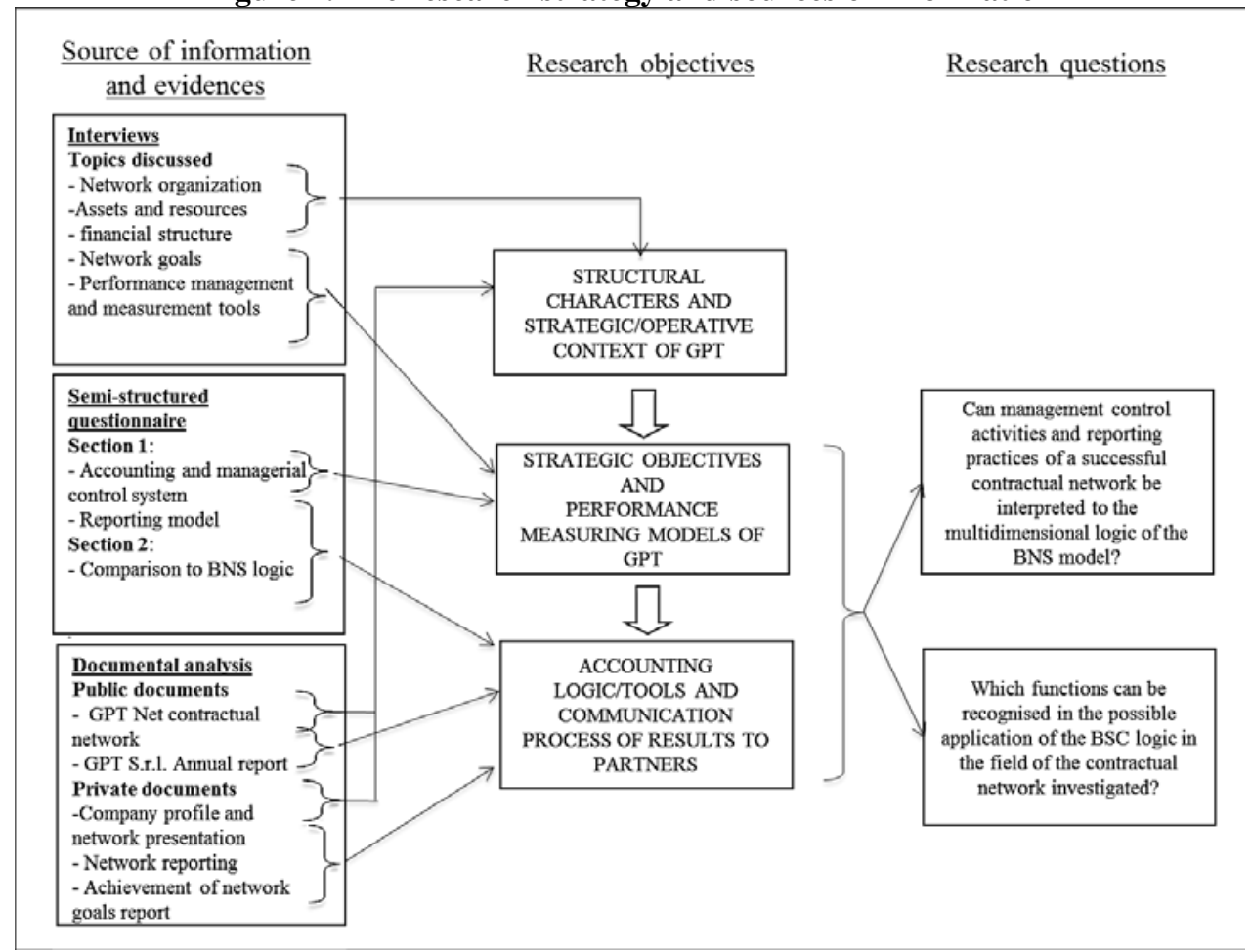

The third problem ${ }^{i i i}$, connected with the dynamism and flexibility of the network, has been faced by devel oping a longitudi nal research in a process-rel ated perspective (Pettigrew, 1997) to take into consideration changes from an operative, organisational and strategic point of view (Halinen \& Törnroos, 1998). The period of time that the analysis refers covers several years, from2005 to 2015.

\section{The case study}

The selected case study is GPT network, an innovative network of companies operating in Umbria (Central Italy) and established ten years ago as experimental outcome of a research project developed by the University of Perugia. The network 
was implemented by Net Value, an academic spin-off of the University, which is al so an associate of thenetwork. Theobjective of thenetwork is to provideintegrated and innovative solutions in the field of communication, printing, packaging and related services. It serves as the sole representative for the customer by benefitting from the joint skills and competences suitable for every solution and it is capable to fully support customer's product and service management.

To date, the network includes 21 partner companies and records a total turnover exceeding 130 million euro, more than 700 employees (approximately $8 \%$ of which dedicated to Research and Development) and 24 production pl ants. Thenetwork was officially set-up in 2005 following the strategic intuitions of three entrepreneurs operating in the print and packaging district of Città di Castello, who decided to set up a limited company (GPT S.r.I.) to sharetheir skills and competences, enlargetheir product portfolio, acquire new customers and provide the global market with innovative products. To reinforce the mutual commitment on assets and competences sharing, a "collaboration agreement" was formal ly signed to strengthen the collaboration towards strategic common goals and objectives.

The role planned for GPT overcomes a pure trading company of paper products, being designed as a coll laborativenetwork strategical ly ai med at product and process innovation. The model was designed on the theoretical model of Virtual Development Office (VDO), acting as a network collector and pointing to themarket as a single organisation whose goal is: i) to identify the competitive position of the companies participating the network; ii) to promote several business opportunities within the network; iii) to define cooperation models and instruments; iv) to monitor performance; v) to favour product innovation and business model innovation.

The current legal structure includes the presence of a limited company, GPT S.r.l., whose shareholders are the 21 partner companies, and the formalization of a contractual network called "GPT Net" in 2012, replacing and reinforcing theoriginal "collaboration agreement".

The section of the contract dedicated to the definition of the strategic objectives contemplates the following objectives:

“(a) to identify new market opportunities and increase the national and international market penetration of the network and of its participants; (b) to encourage research and devel opment of new products and/or services and the innovation of technological and management processes; (c) to share and develop transversal services in order to optimise qual ity and reduce costs; (d) to identify opportunities for access to credit, private and public funding (e) to increase and diffuse technical and management skills within the network". 
The network programme considered in the contract includes:

"identification of new projects and/or specific market opportunities; development of coordinated forms of promtion of the products and services of the network partici pants, in I taly and abroad, al so in the formof integrated solutions that include the products and services of two or more participant companies of the network; management and coordination of the negotiation, acquisition and execution phases of projects to be carried out in the network; identification, coordination and management of research, development and innovation activities useful for the network and its participants; identification of possible financial opportunities and public grants and management of request phases; identification, coordination and management of business opportunities to reinforce the technical and management skills of the network and of its participants".

With reference to the measuring models of progress towards the strategic objectives, the following was considered:

"in each calendar year the Management Authority will check progress towards the strategic objectives in the final annual report, to be presented by $30^{\text {th }} \mathrm{J}$ une of the following year to all network participants".

With regards to governance, the contract includes the creation of a common Management Authority in charge of executing the network programme, to whom a mandate with representation was entrusted. For the entire duration of the contract, the company GPT S.r.l. was nominated to carry out this role, thus, its pro tempore legal representatives are thekey managers in charge of making decisions on relevant issues.

\section{The balanced scorecard for company networks: the first research findings}

Theliterature analysis of BSC (Kaplan \& Norton, 1996) as programming and control tool, or network performance reporting for external purposes (Marchi, 2011), al lows for a control of thestrategic-operative rel evance of such tool for companies network. In other words, the use of a tool aimed at identifying the financial and non-financial performance of the network is proposed, enhancing the mutual activities carried out by the companies' network.

TheB usiness Network Scorecard was applied ex-post to GPT network (Lombardi et al., 2015) through the following operative instruments: i) matrix of the network objectives; ii) multidimensional report that indicates network performance through financial and non-financial measures; iii) comparison chart between network performance and the totalled performance of the partnering companies.

The BNS was applied according to data provided by GPT documents (network programme report; management annual report, joint bal ance sheet data, etc.) as well 
as by interviews carried out in order to test the relevance of this tool for network management control and for the network performance reporting to stakehol ders.

When the project started, GPT network was adopting traditional control tools, mainly deriving from a calculation of the financial statement indicators and from forecasts on network performance according to the objectives to be pursued in the network. The individual appointed for network strategic control was the network manager, an expression of the academic element of the Net Value spin-off. Starting with the matrix of the network objectives, the main strategic objectives of the GPT network are summarised in the following table (Table 2).

Table 2. 0 bjectives/M easures of the G PT network

\begin{tabular}{lll}
\hline \multicolumn{1}{c}{ OBJ ECTIVES } & \multicolumn{1}{c}{ M EASUR E S } \\
\hline MARKET & $*$ & Marketing action \\
& $*$ & Business development \\
& $*$ & Contacts with customers \\
& $*$ & $\begin{array}{l}\text { Participation in tenders } \\
\text { Internal coordination activities in order to } \\
\text { understand and handle the activities aimed at } \\
\text { creating a new product (for example, printing of } \\
\text { degree certificates) }\end{array}$ \\
PRODUCT INNOVATION & $* \begin{array}{l}\text { Synergy research through primary processes } \\
\text { (mutual purchases) or support (mutual } \\
\text { certification) }\end{array}$ \\
INTERBUSINESS AND & $* \begin{array}{l}\text { Research activities (degreethesis) to understand } \\
\text { the opportunities of supplies fromabroad }\end{array}$ \\
PROCURORATIVE & & \\
RESEARCHENT AND &
\end{tabular}

The matrix of objectives of BNS model is composed of five profiles or key perspectives, in order to measure and report network performance from a multidimensional point of view. The five main profiles for performance measuring, included in the multidimensional logic in which the GPT network is created, are divided up into the following perspectives: economic-financial; customers; internal processes; development and growth; value creation.

In the economic-financial perspective, the general objectives of the GPT network can be discovered, for example, in business development and in economic-financial returns of the joint activities by network. The customer perspective results in an objective of the added value creation for this category of stakeholders. The perspective of internal processes refers to the objectives of product creation and/or the supply of services. The perspective of development and growth of the network is based on the adoption of innovative processes, including investments in intellectual capital. The perspective of value creation measures the added value of network activities of a social, environmental and intellectual capital nature. 
The BNS multidimensional report applied to GPT consists in the presentation of a network balanced assessment form, with the five perspectives as indicated above. The report includes a set of key indicators measuring GPT performance, which can be used as a network management control tool (e.g. to monitor partners' activities), a communication instrument to the network stakeholders and a tool to identify and disclose the amount and type of strategic intangible assets acquired or developed. Some examples include the indicators proposed to measure the network devel opment, generated froman anal ysis of theinnovations and investments in R\&D and the metrics used to assess network's value creation with reference to social and environmental initiatives.

The data indicated in the multidimensional report applied to the GPT case refers to a time period of approximately 10 years, starting from the year in which the network was created in 2005. By analysing the perspectives of the multidimensional network report, performance indicators measured by the GPT network in the management annual report can be found as well as a set of useful information in order to define the combined operative strategy. Starting with the economic-financial perspective, the indicators attributed and established for GPT illustrate the ones proposed by the BNS model through four main categories of performance indexes and a good level of sub-indicators: GPT share capital, GPT profit/loss, proceeds of the network, network activity value. The combined ROE can be found among the additional indicators. The indicators of the customer perspective have been applied through the five categories indicated in the model, including a good level of sub-indicators: number of customers/contracts from the network; customer satisfaction level, number of complaints (production non-compliances), reputation of the network, additional indicators. Among these, the additional indicators are very original (Large Accounts, Wide Markets, Special Markets), as they aim to segment the GPT market. The internal processes are represented by the application of four categories of indicators and sub-indicators: the number of research projects launched by the network, production costs of goods and/or the supply of services, the number of employees in the network, equal opportunities. Additional indicators have not been defined. Network devel opment and its indicators represent a very important analysis perspective for the GPT network, within which the following indicators are classified: investments in training of human capital, process and product innovations, network patents, $R \& D$ costs, additional indicators. The val ue creation perspective illustrates the most representative indicators of intangible performance of GPT (social, environmental and intellectual capital), through five categories of indicators: added value of the network and social initiatives, environmental impact and certifications, stakeholders, transfer of knowledge, additional indicators. 


\begin{tabular}{|c|c|c|c|c|c|}
\hline & 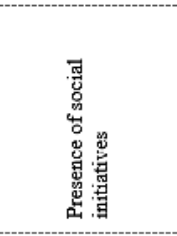 & 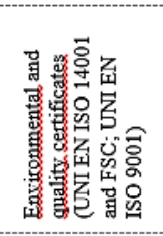 & 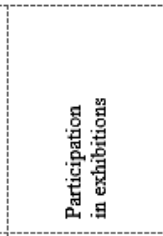 & 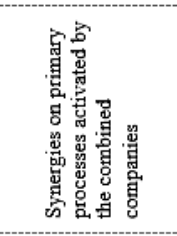 & 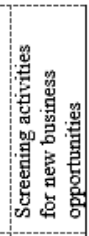 \\
\hline & 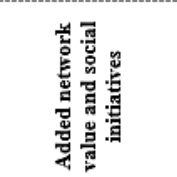 & 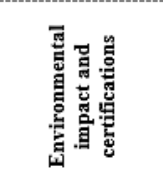 & 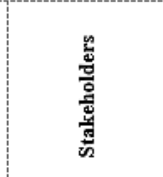 & 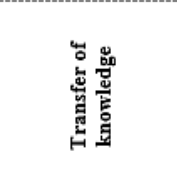 & 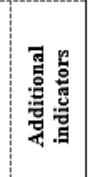 \\
\hline & 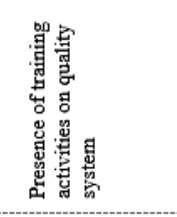 & 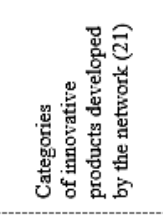 & 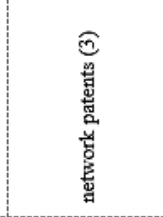 & 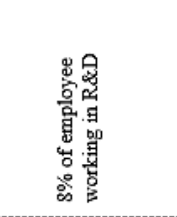 & 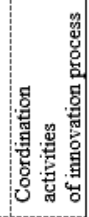 \\
\hline & 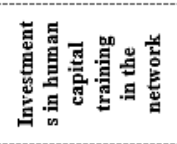 & 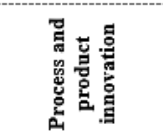 & 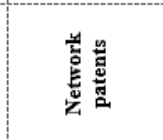 & 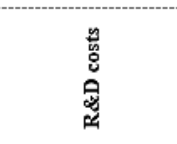 & 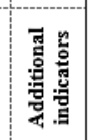 \\
\hline & 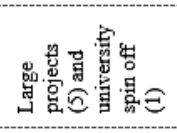 & 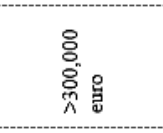 & 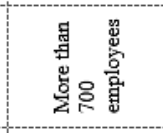 & 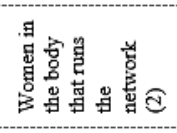 & \\
\hline & 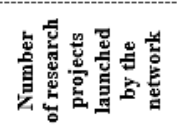 & 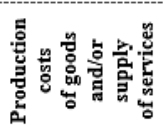 & 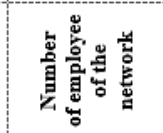 & 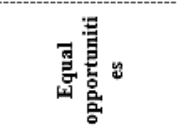 & 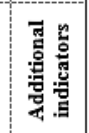 \\
\hline & 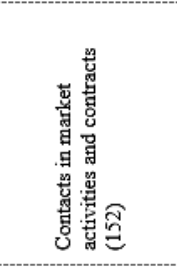 & 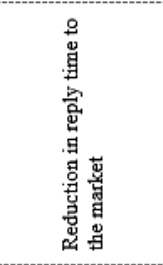 & 总 & 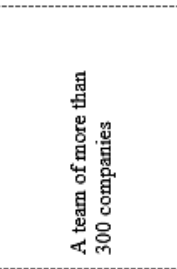 & 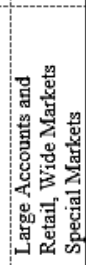 \\
\hline & 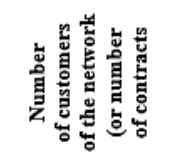 & 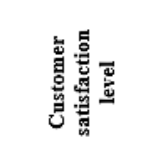 & 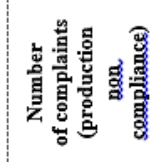 & 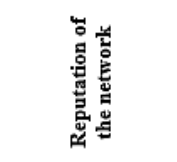 & 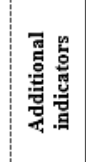 \\
\hline & 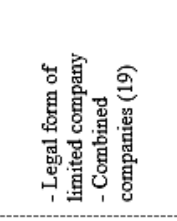 & 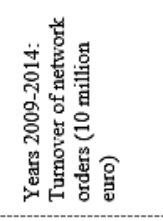 & 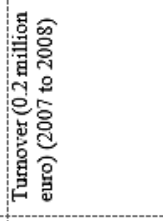 & 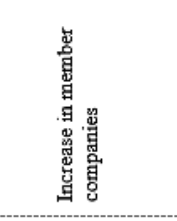 & 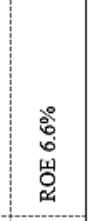 \\
\hline : & 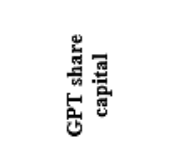 & 点莺 & 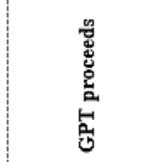 & 总善 & 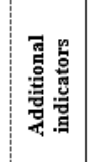 \\
\hline
\end{tabular}


The last element of the BNS model, the combined network- total companies performance form, has not been applied in this phase of the research.

\section{Discussions and concluding remarks}

Based on the GPT case, we can state that the Business Network Scorecard model is consistently fitting ex-post with the strategic, operative and reporting activities of the network, representing a useful managerial instrument that can be implemented into real life settings of collaborative processes.

With reference to the first research question, the case demonstrates how the strategic and operational goal setting as well as the managerial annual report contain the perspectives indicated by BNS, even in the absence of deliberate adoption of the BSC Iogic. Indeed the GPT case shows a significant coherence and integration between strategic objectives, short-termactivities and results, measured by financial and non-financial indicators (Atkinson, 2006). Particularly strong is the alignment between the strategic decisions and the selection, measurement and control of financial and intangible performance (Glavan et al., 2007). This integrated logic influences the whol e set of reporting documents el aborated by the network manager to comply with institutional and managerial needs, from sharehol ders and partners meetings to quality assurance, and define a management control approach able to support the emergent and deliberate components of strategic management process.

However, an incomplete application of the multidimensional report of the GPT network can befound, as well as theneed to extend analysis times of GPT data to be reclassified in the BNS. The objective is to propose a combi ned management control system to identify financial and non-financial network performance, to transfer useful information inside and outside of the network, with a view to programming and control and also for accounting of the intangible performance to network stakeholders.

Furthermore, the integration of sector-specific indicators is missing. In Table 3 we include some possi bl eindicators whose validity must bechecked with regards to the GPT case, through a sample of networks operating within the same sector.

Table 4. Sector indicators of the BNS-G PT model

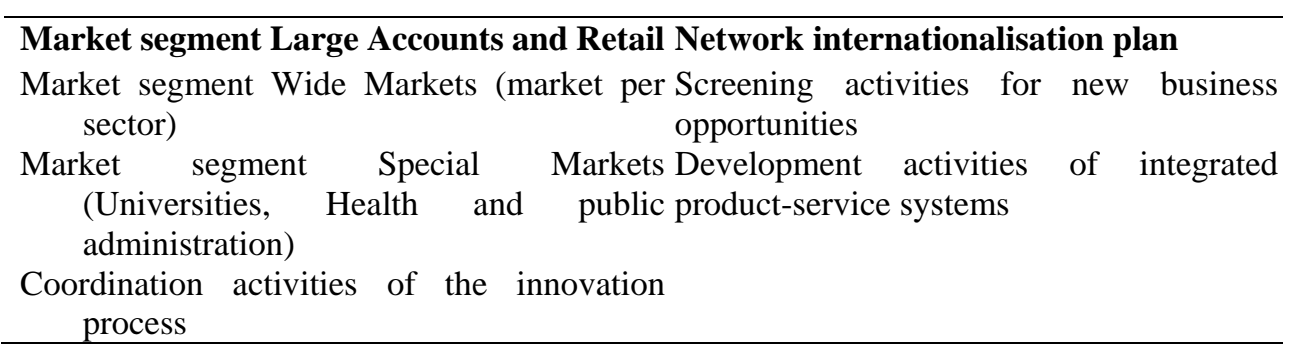


Moving onto the second research question, the paper suggests that since the network set-up the BSC logic has played a very important role in defining the network mission (Neely et al., 2000), communicating the project to potential partners (Marchi, 2011) and guiding the formalisation of the strategic objectives onto the network contract (Pekkola, 2013). The adoption of the mul tidimensional perspective on the management annual report presented at the meetings of partners called to approve the annual results indicate that the BSC logic has supported the control process and accounting of the network activities over the years (CIMA, 2015). Based on the report structure and contents an important training function can al so be found, aimed at favouring learning and involvement of the partners whose trust and commitment was perceived as a fundamental asset by the network manager. Final ly, thanks to the basic coherence between strategic objectives, progress achieved and new planned objectives, the BSC logic undertakes a vital role in the construction, analysis and communication of the intangible assets. This al lows network manager to measure and report intangible performance that otherwise would not have been expressed, creating a general commitment on the validity of the strategic project for partners and the managerial team.

With specific reference to Simons' framework implemented as in Van Veen-Dirks and Wijn (2002) the GPT case showed a diagnostic use of the Bal anced Scorecard logic. A nalysing the form of themanagement report and the minutes of the meetings, the case showed a top-down flows of information from the network manager to partners with the specific aim to communicate results and create commitment Even considering the collaborative and active role that partners play in the network context, which is not comparable to operating managers of a verticalized organization, the interactive use of management control system it is not visi ble. The report is elaborated to demonstrate the ful filment of strategic objectives and to link the operational activities with long-term goals. A specific session of the report was al ways devoted to present new strategic initiatives and collaborative projects, but it was not conceived as an output of the discussion on information reported. To this extant, a stronger involvement of the partners on strategic and operational activities to the network should be necessary to put them in the condition to interactively interpret and discuss the information, creating the premises for strategy adjustments and possible revisions. A formal adoption of the Balanced Scorecard logic through BNS, followed by joint periodic discussion, could help in this way.

Summarising, the BSC logic adoption supported network devel opment and stability. To this regard it cannot beignored the important roleplayed by thenetwork manager and the academic spin-off Net Value in explicity integrating the strategic perspective and performance measures as well as financial and non-financial indicators. To this respect, the managerial team succeeded in overcoming the typical weaknesses of SMEs, where owner-entrepreneurs intuitively integrate financial indicators with non-financial indicators but fail in the implementation of the needed routines and formal ization to adopt the BSC logic successfully (J arvis et al., 2000). 
We can conclude that the mandatory requirements establi ished by the legislation on contractual networks could represent a relevant opportunity for SMEs to improve their managerial practice in business planning and performance management, both at individual and collaborative level. Moreover, if SMEs adopt the BSC logic they can better overcomethe difficulties in devel oping the network's mission and strategy formulation that hinder the implementation of a performance measurement system (Ates et al., 2013). As stated by Garengo and Biazzo (2012), the BSC approach can help network partners to unveil the strategy, improving themanagerial culture of the whole network and every single partner.

\section{R eferences}

Ahn, H. (2001) "A pplying the bal anced scorecard concept: an experience report", Long Range Planning, vol. 34(4): 441-461.

Alonso, A.D. (2010) "Importance of relationships among small accommodation operations around the city of Perth", Tourismand Hospitality Research, vol. 10(1): 14-24.

Anderson, E.W., Fornell C. \& Lehmann. D.R. (1994a) "Customer satisfaction, market share, and profitability: findings from Sweden", J ournal of Marketing, vol. 58(3): 53-66.

Anderson, J.C., Håkansson, H. \& J ohanson, J. (1994b) “Dyadic relationships within a business network context", J ournal of Marketing, vol. 58(4): 1-15.

Ates, A., Garengo, P., Cocca, P. \& Bititci, U. (2013) "The development of SME managerial practice for effective performance management", J ournal of Small Business and Enterprise Devel opment, vol. 20(1): 28-54.

Atkinson, H. (2006) "Strategy implementation: a role for the bal anced scorecard?", Management Decision, vol. 44(10): 1441-1460.

Aureli, S. \& Del Baldo, M. (2016a) Formal Inter-firm Cooperation and International Expansion: How Italian SMEs are Using the Network Contract, in Etemad. H., Denicolai, S., Hagen, B. \& Zucchella A (ed) The Changing Global Economy and its Impact on International Entrepreneurship. The McGill International Entrepreneurship series, Cheltenham, UK: Edward El gar Publishing, 157-182.

Aureli, S., Del Baldo, M. (2016b) “Performanceappraisal of business networks. how small and medium enterprises define and monitor network objectives", Management Control, vol. 1: 35-58.

Aureli, S. \& Forlani, F. (2016) "The importance of brand architecture in business networks: The case of tourist network contracts in I taly", Qual itative Market Research: An International J ournal, vol. 19(2): 133-155.

Barnes, D., Clear, F., Dyerson, R., Harindranath, G., Harris, L. \& Rae, A. (2012) "Web 2.0 and micro-businesses: an exploratory investigation", J ournal of Small Business and Enterprise Development, vol. 19(4): 687-711. 
Bititci, U., Mendibil, K., Martinez, V. \& Albores, P. (2005) "Measuring and managing performance in extended enterprises", International J ournal of Operations \& Production Management, vol . 25(4): 333-353.

Bourne, M., Mills, J., Wilcox, J., Neely, A. \& Platts, K. (2000) “Designing, implementing and updating performance measurement systems", International J ournal of Operations \& Production Management, vol . 20(7): 754-771.

Brouthers, K., Andriessen, F. \& Nicolaes, I. (1998) "Driving blind: strategic decision-making in small companies", Long Range Planning, vol. 31(1): 130-138.

Busco, C. \& Quattrone, P. (2015) “Expl oring How the Balanced Scorecard Engages and Unfolds: Articulating the Visual Power of Accounting Inscriptions", Contemporary Accounting Research, vol. 32(3): 1236-1262.

Camarinha-Matos, L.M., Afsarmanesh, H., Galeano, N. \& Molina, A. (2009) "Collaborative networked organizations - concepts and practice in manufacturing enterprises", Computers \& Industrial Engineering, vol. 57(1): 46-60.

Cardoni, A. (2012) "Business planning and management accounting in strategic networks: theoretical development and empirical evidencefromenterprises' network agreement", Management Control, vol. 3: 91-116.

Cepiku. D., Bianchi, A., Capaccioli, C., Costanzo, G. \& Spandonaro, F. (2011) “Un model lo per la misurazione delle performance delle reti: il caso studio del network antimal aria Tigray", PoliticheSanitarie, vol. 12(3): 101-115.

Cerved (2015) Rapporto Cerved PMI 2015. Milano: New Copy Service.

CIMA (2005) Effective Performance Management with the Balanced Scorecard. The Chartered Institute of Management Accountants, London.

Del Baldo, M. (2016) "Formal Cooperation for Developing Sustainability and Corporate Social Responsibility Among Tourism SMEs in Italy: Insights, Limits and Potentialities of the Network Contract", in I dowu, S.O. (ed.) Key Initiatives in Corporate Social Responsibility. Global Dimension of CSR in CorporateEntities, Vienna: Springer Series CSR Sustai nability, 103-129.

Dobbs, M. \& Hamilton, R.T. (2007) "Small business growth: recent evidence and new directions", International J ournal of Entrepreneurial Behaviour and Research, vol. 13(5): 296-322.

Dubois, A. \& Gadde, L.E. (2002) "Systematic combining. An abductive approach to case studies", J ournal of Business Research, vol. 55(7): 553-560.

Easton, G. (1995) "Methodology and industrial networks", in Möller, K, Wilson, D.T. (ed), Business marketing: an interaction and network perspective, Norwell, MA: Kluwer Academic Publishing, 411-491.

Eccles, R.G. (1991) "The performance measurement manifesto", Harvard Business Review, vol. 69(1):131- 137.

Edvinsson, L. \& Malone, M. (1997) Intel lectual capital: Realising your company's true value by finding its hidden brain-power, New Y ork: Harper Collins. 
Eisenhardt, K.M. (1989) "Building theories from case study research", Academy of Management Review, vol. 14(4): 532-550.

Epstein, M.J . \& Manzoni, J.F. (1997) "The bal anced scorecard and tabl eau de board: translating strategy into action", Management Accounting (USA), vol. 79(2): 28-37.

European Commission (2008) Think Small First. A Small Business Act for Europe. http://eur-lex.europa.eul

European Commission (2011) Review of the Small Business Act for Europe http://eur-lex.europa.eul

Ferraris Franceschi, R. (1990) II modello della ricerca, Milano: Giuffrè

Fernhaber, S. \& Li, D. (2013) “International exposure through network relationship: implication for new venture internationalization", Journal of Business Venturing, vol. 28(2): 316-334.

Ferreira, P., Shamsuzzoha, A.H.M., Toscano, C. \& Cunha, P. (2012) "Framework for performance measurement and management in a collaborative business environment", International J ournal of Productivity and Performance Management, vol. 61(6): 672-690.

Fichter, K. (2009) "Innovation communities: the role of networks of promoters in Open Innovation", R\&D Management, vol. 39(4): 357-371.

Flick, U. (2009), An Introduction to Qualitative Research, Sage, London, UK.

Funk, E. (2007) "The balanced scorecard equates interest in healthcare organizations", J ournal of Accounting \& Organizational Change, vol. 3(2): 88-103.

Garengo, P. \& Biazzo, S. (2012) “Unveiling strategy in SMEs through balanced scorecard implementation: A circular methodology", Quality Management and Business Excellence, vol. 23(1): 79-102.

Glavan, M.E., Braescu, M., Dumitru, V., Jinga, G. \& Laptes, R. (2007) “The relevance and quality of the accounting information in the managerial decisions", Accounting and Management Information Systems, Supplement, 103-115.

Håkansson, H., Ford, D., Gadde, L.E., Shenota, I. \& Waluszewski, A. (2009). Business in Network, New Y ork: John Wiley \& Son Ltd.

Halinen, A., Törnroos, J.A. (1998) "The role of embeddedness in the evolution of business networks", Scandinavian J ournal of Management, vol. 14(3): 87-205.

Halinen, A. \& Törnroos, J.A. (2005) "Using case methods in the study of contemporary business networks", J ournal of Business Research, vol. 58(9): 1285-1297.

Hudson. M., Smart, P.A. \& Boume, M. (2001a) "Theory and practice in SME performance measurement systems", International J ournal of Operations and Production Management, vol. 21(8):1096-1116.

Hudson, M., Lean, J. \& Smart, P.A. (2001b) "Improving control through effective performance measurement in SMEs", Production Planning and Control, vol. 12(8): 804-813. 
Huggins, R. (2001) Inter-firmnetwork policies and firm performance: eval uating the impact of initiatives in the United Kingdom", Research Policy, vol. 30(3): 443-458.

Jänkälä, S. (2007) Management Control Systems (MCS) in the Small Business Context. Linking effects of contextual factors with MCS and financial performance of small firms, Acta Universitatis Oulu, Ouluensis, G Oeconomica, 30.

J arvis, R., Curran, J., Kitching, J . \& Lightfoot, J. (2000) "The use of quantitativeand qualitative criteria in the measurement of performance in small firms", J ournal of Small Business and Enterprise Development, vol. 7(2): 123-134.

Kaplan, R.S. \& Norton, D.P. (1996) “Using the Balanced Scorecard as a Strategic Management System", Harvard Business Review, J anuary-February, 75-85.

Kaplan, R.S. \& Norton, D.P. (2001) "Transforming the balanced scorecard from performance measurement to strategic management: part II.", Accounting Horizons, vol. 15(2): 147-160.

Kaplan, R.S. \& Norton, D.P. (2004), Strategy Maps Converting Intangible Assets into Tangible Outcomes, Boston, M: Harvard Business School Press.

Kaplan, R.S., Norton, D.P. \& Rugelsjoen, B. (2010) "Managing alliances with the bal anced scorecard", Harvard Business Review, vol. 88(1/2): 114-121.

Kim, D.H. \& Kim, C. (2009), A Generic Framework of Performance Measurement in Networked Enterprises, in Camarinha-Matos L.M., Paraskakis I., Afsarmanesh $H$. (eds) Leveraging Knowledge for Innovation in Collaborative Networks, Berlin: Springer, 259-265.

Kulmala, H.I. \& Lönnqvist, A. (2006) "Performance measurement of networks: towards a non-financial approach", International J ournal of Networking and Virtual Organizations, vol. 3(3): 299-316.

Lai honen, H., Jääskeläinen, A. \& Pekkola, S. (2014) "Measuring performance of a service system - from organizations to customer-perceived performance", Measuring Business Excellence, vol. 18(3): 73-86.

Laitinen, E.K. (2002) "A dynamic performance measurement system: evidencefrom small Finnish technology companies", Scandinavian J ournal of Management, vol. 18(1): 65-99.

Lawrie, G. \& Cobbold, I. (2004) “Third-generation balanced scorecard: evolution of an effective strategic control tool", International J ournal of Productivity and Performance Management, vol. 53(7); 611-623.

Lin, F. \& Lin, Y. (2016) "The effect of network relationship on the performance of SMEs", J ournal of Business Research, vol. 69(5): 1780-1784.

Lombardi, R. (2015), Le reti d'impresa in economia aziendale. Profili critici e interpretativi, Torino: Giappichelli.

Lombardi, R., Caputo, A., Russo, G. \& Formisano, V. (2015) “Management control of contractual networks: the business network scorecard", International J ournal of Applied Management Science, vol. 7(4): 269-286. 
Mahama, H. (2006) “Management control systems, cooperation and performance in strategic supply relationships: a survey in the mines", Management Accounting Research, vol. 17(3): 315-339.

Mancini, D. (2016) "Accounting Information Systems in an Open Society. Emerging Trends and Issues", Management Control, vol. 1: 5-16.

Marchi, L. (2011) “L'evoluzione del controllo di gestione nella prospettiva informativa e gestionale esterna", Management Control, vol. 3: 5-16.

Marr, B. (2004) "Mapping the dynamics of how intangibles create value", International Journal of Learning and Intellectual Capital, vol. 1(3): 358-369.

Marr, B., Schiuma, G. \& Neely, A. (2004) "The dynamics of value creation mapping your intel lectual performance drivers", J ournal of Intel lectual Capital, vol. 5(2): 312-325

Mastilak, C., Matuszewski, L., Miller, F. \& Woods, A. (2012) “Evaluating conflicting performance on driver and outcome measures: the effect of strategy maps", J ournal of Management Control, vol. 23(2): 97-114.

Mooraj, S., Oton, D. \& Hostetter, D. (1999) "The balanced scorecard: a necessary good or an unnecessary evil?", European Management J ournal, vol. 17(5): 481-491.

Naro, G. \& Travaillé, D. (2011) "The role of the balanced scorecard in the formulation and control of strategic processes", J ournal of Applied Accounting Research, vol. 12(3): 212-233.

Neely, A., Mills, J., Platts, K., Richards, H., Gregory, M., Bourne, M. \& Kennerley, M. (2000) "Performance measurement system design: developing and testing a process-based approach", International J ournal of Operations \& Production Management, vol. 20(10): 1119-145.

Neely, A., Adams, C. \& Crowe, P. (2001) "The performance prism in practice", Measuring Business Excellence, vol. 5(2): 6-13.

Parung, J. \& Bititci, U. (2008) "A metric for collaborative networks, business process", Management J ournal, Vol. 14(5): 654-674.

Pekkola, S. (2013) "Managing a network by utilizing performance measurement information", Measuring Business Excellence, vol. 17(1): 72-79.

Pettigrew, A. (1997), "What is processual analysis?", Scandinavian J ournal of Management, vol. 13(4): 337-348.

Ryan, B., Scapens, R.W. \& Theoblad, M. (2007), Research Method and Methodology in Finance and Accounting, London: Thomson.

Saetta, S., Tiacci, L. \& Cagnazzo, L. (2013) "The innovative model of the Virtual Development Office for collaborative networked enterprises: the GPT network case study", International J ournal of Computer Integrated Manufacturing, vol. 26(1-2): 41-54.

Simons, R. (1995), Levers of Control. How Managers Use Innovative Control Systemto Drive Strategic Renewal, Boston, MA: Harvard Business School Press. 
Stewart, T.A. (1997), Intellectual capital. The new wealth of organization, New Y ork, NY : Doubleday.

Strohhecker, J. (2016) "Factors influencing strategy implementation decisions: an eval uation of a balanced scorecard cockpit, intelligence, and knowledge", J ournal of Management Control, vol. 27(1): 89-119.

Sveby, K.E. (1997), The new organizational wealth. Managing and measuring knowledge-based assets, San Francisco, CA: Berret-Koehler Publ ishers.

Trequattrini, R., Russo, G. \& Lombardi, R. (2012) "Network governance: organizational and legal profiles", Corporate Ownership \& Control, vol. 9(4): 346-350.

UnionCamere, (2016), "Statistiche dei contratti di rete". Retrieved from http://www.infocamere it/contratti-di-rete. Accessed: December, 3, 2016.

van en Veen-Dirks, P. \& M. Wijn (2002) "Strategic control: meshing critical success factors with the balanced scorecard", Long Range Planning, vol. 35(4): 407-427.

Varamäki, E. \& Vesalainen, J. (2003) “Modelling Different Types of Multilateral Co-operation between SMEs", Entrepreneurship and Regional Development, vol. 15(1): 27-47.

Varamäki, E., Kohtamaki, M., Jarvenpaa, M., Vuorinen, T. \& Laitinen, E. (2008) “A framework for a network-level performance measurement system in SME networks", International J ournal of Networking and Virtual Organisations, vol. 5(3-4): 415-435.

Verschoore, J.R., Wegner, D. \& Bal estrin, A. (2015) “Theevolution of collaborative practices in small-firm networks: a qualitative analysis of four Brazilian cases", International J ournal of Management Practice, vol. 8(2): 152-168.

Y in R.K. (1989) Case study research-design and methods, 2nd edn. Newbury Park, CA: Sage Publications.

Zapata, M.J. \& Hall, C.M. (2012) "Public-private collaboration in the tourism sector: balancing legitimacy and effectiveness in local tourism partnerships. The Spanish case", J ournal of Policy Research in Tourism Leisure \& Events, vol. 4(1): 61-83.

i Section 4-ter and following of LD no. 5 of 10th February 2009; Law 9 A pril 2009, No. 33 as amended by Law No. 122/2010.

ii An analysis of cases favours investigation into concrete experience or new areas of research (Yin, 1989), as well as the understanding of the nature of accounting practices and managerial and control systems (Bititci et al., 2005; Ryan et al., 2007).

iii The problem of comparability (with other networks, industries and countries, or their combination) does not apply as this study focuses on one single case. 